\title{
The Occurrence and Fine Structure of Merkel Cells in the Lingual Epithelium of the Turtle, Clemmys japonica
}

\author{
By \\ Kuniaki TOYOSHIMA, Yuji SETA and Akitatsu SHIMAMURA \\ Department of Oral Anatomy, Kyushu Dental College, Kokurakita-ku, Kitakyushu, 803 Japan \\ - Received for Publication, March 29, $1993-$
}

Key Words: Merkel cell, Lingual epithelium, Turtle, Ultrastructure

\begin{abstract}
Summary: Electron microscopic examination of the lingual mucosa of the turtle, Clemmys japonica, revealed the occurrence of Merkel cells that shared many morphological features with Merkel cells in other vertebrates. Merkel cells were located exclusively in the basal portion of the epithelium near the taste buds. We also found occasional Merkel cells devoid of nerve contact. Nerve terminals approaching these non-innervated Merkel cells were occasionally found in the connective tissue just beneath these cells.
\end{abstract}

It has been reported that Merkel cells appear in the skin and oral mucosa of all vertebrates (Halata, 1975; Saxod, 1978; Hartschuh et al., 1986; Whitear, 1989; Toyoshima and Shimamura, 1991). However, there are few morphological studies of Merkel cells in reptiles compared with the large number of studies on these cells in other vertebrate classes.

In her study on the fine structure of the skin of Caiman crocodilus, Düring (1975) found Merkel cellneurite complexes in the dermis of this animal. Landmann and Halata (1980), on the other hand, reported the presence and ultrastructural details of Merkel cells in the labial epidermis of a lizard, Lacerta sicula. Recently, Watanabe (1988) reported the occurrence of Merkel cells in the gingival epithelium of the tegu lizard, Tupinambis teguixin. Thus the location of Merkel cells, dermis or epidermis, varies among reptiles.

Despite the fact that Merkel cells appear in large numbers in the oral mucosa, studies of these cells in the lingual mucosa have been relatively few among vertebrates (Toyoshima et al., 1987). While investigating the morphology of the turtle tongue, we found numerous Merkel cells, which are located exclusively in the epithelium of this organ. The present paper briefly describes the fine structure of these cells in the turtle lingual epithelium.

\section{Materials and Methods}

Two turtles, Clemmys japonica, were used in this study. After anesthetizing the animals deeply with sodium pentobarbital $(50 \mathrm{mg} / \mathrm{kg})$, the tongues were dissected free and placed in a trialdehyde-DMSO mixture (Kalt and Tandler, 1971) buffered with phosphate, then the specimens were cut into small pieces and immersed in the same fixative for 3 hours. These specimens were postfixed for 2 hours in phosphatebuffered $2 \%$ osmium tetroxide, dehydrated in a series of ethanols, passed through propylene oxide, and embedded in Epon-Maraglas (Tandler and Walter, 1977). Semithin sections were stained with toluidine blue and examined by light microscopy. Thin sections for electron microscopy were stained with uranyl acetate followed by lead citrate, and examined in a JEM-1200EX electron microscope.

\section{Results}

The dorsal surface of the tongue consists of folds or wrinkles and is covered by nonkeratinized stratified squamous epithelium. Merkel cells appear in the basal portion of the epithelium lining the folds and can be identified easily as less intensely stained cells than the surrounding keratinocytes by both light and electron microscopy. Most Merkel cells are ovoid in shape, ranging from $8-10 \mu \mathrm{m}$ in diameter, and possess highly lobulated nuclei.

At the electron microscopic level, the most conspicuous feature of Merkel cells is the presence of numerous dense-cored granules, ranging from $80-100 \mathrm{~nm}$ in diameter, in the cytoplasm. The density of the contents of granules is variable. These granules are distributed preferentially in the basal cytoplasm. The Golgi complexes are alway's located in the supranuclear cytoplasm opposite the major 
aggregation of dense-cored granules. A few densecored granules appear sometimes in the Golgi area. Centrioles are observed occasionally near the Golgi region. Mitochondria, lysosomes and cytoplasmic filaments in varying numbers are also components of Merkel cells.

Another characteristic feature of Merkel cells is the presence of long microvilli, about $3-4 \mu \mathrm{m}$ in length, extending into the intercellular spaces between the neighboring keratinocytes. These microvilli contain a parallel pattern of numerous filaments. Merkel cells are connected with adjacent keratinocytes by small desmosomes.

Nerve terminals closely associated with the basal plasma membrane of the Merkel cell are often observed. These terminals contain synaptic-type vesicles, small mitochondria and abundant glycogen particles. Junctional specializations are sometimes observed between Merkel cells and the associated nerve terminals. These are characterized by symmetrical thickenings of plasma membranes of the Merkel cell and apposed axon.

Occasionally, Merkel cells devoid of nerve contact and adjoining directly to the basal lamina are observed. In these cases, the dense-cored granules of these Merkel cells are relatively small in size, ranging from 60 to $80 \mathrm{~nm}$ in diameter, are less electron-dense and tend to accumulate in the cytoplasm toward the basal lamina, where numerous mitochondria are located. Microvillar projection is rare in this type of Merkel cell. Nerve terminals occasionally appear in the subepithelial connective tissue just below these Merkel cells.

\section{Discussion}

The present study examined the occurrence and fine structure of Merkel cells in the lingual epithelium of the turtle. Merkel cells were located exclusively near the basal portion within the epithelium. This is in accord with observations in the lizard by Landmann and Halata (1980). The morphology of Merkel cells in the turtle fulfilled all the criteria described by other authors (reviews, see Whitear,
1989): 1) localization restricted to the epithelial basal layer, 2) presence of characteristic dense-cored granules in the cytoplasm, 3) microvillar projections extending into the intercellular space of the neighboring epithelial cells, and 4) desmosomes on the cell surface.

Since Merkel first described a distinct type of cells as "Tastzellen" in 1875, the Merkel cell has been considered to be a mechanoreceptor on the basis of its morphology and physiology. According to this concept, the Merkel cell senses mechanical deformation by its microvillar projections and releases transmitters to the associated nerve terminals. Several transmitter candidates have been reported from immunohistochemical studies (Hartschuh et al., 1989). It has been speculated, further, that these bioactive substances are stored in the densecored granules and coexist with chromogranin A (Hartschuh et al., 1989).

Recently, evidence has accumulated suggesting that Merkel cells may have a trophic effect on the mechanosensory nerve fibers (Diamond et al., 1988). Electrophysiological studies have also provided evidence that not the Merkel cell but the nerve terminals juxtaposed to these cells are the mechanoelectric transducer elements (Gottschaldt and Vahle-Hinz, 1982). Merkel cells may act as target sites for mechanosensory axons (Diamond et al., 1988).

In the present study, we found occasional Merkel cells devoid of nerve contact. These non-innervated Merkel cells usually lacked microvillar projections. Further, we occasionally found nerve terminals approaching non-innervated Merkel cells in the connective tissue just below these cells. Although circumstantial, these findings seem to favor the view that Merkel cells may act as target sites for nerve fibers. It is of interest to note the finding obtained by Morohunfola et al. (1992) that the initial differentiation of Merkel cells appeared to occur before the arrival of nerve terminals in the epidermis. Recently, Vos et al. (1991) demonstrated nerve growth factorimmunoreactivity in Merkel cells. This study strongly supports a trophic role for Merkel cells.

\section{Explanation of Figures}

\section{Plate I}

Fig. 1. Light micrograph showing lingual epithelium of the turtle. Merkel cells (arrows) are seen in the basal portion of the epithelium. (asterisk: taste bud) $\times 280$.

Fig. 2. Electron micrograph of a Merkel cell (M) and associated nerve terminal (N). Numerous dense-cored granules are accumulated in the infranuclear cytoplasm, while Golgi complexes are located in the supranuclear cytoplasm opposite the aggregation of dense-cored granules. Microvillar projections extend to the surrounding epithelial cells (arrows). $\times 11,000$ 


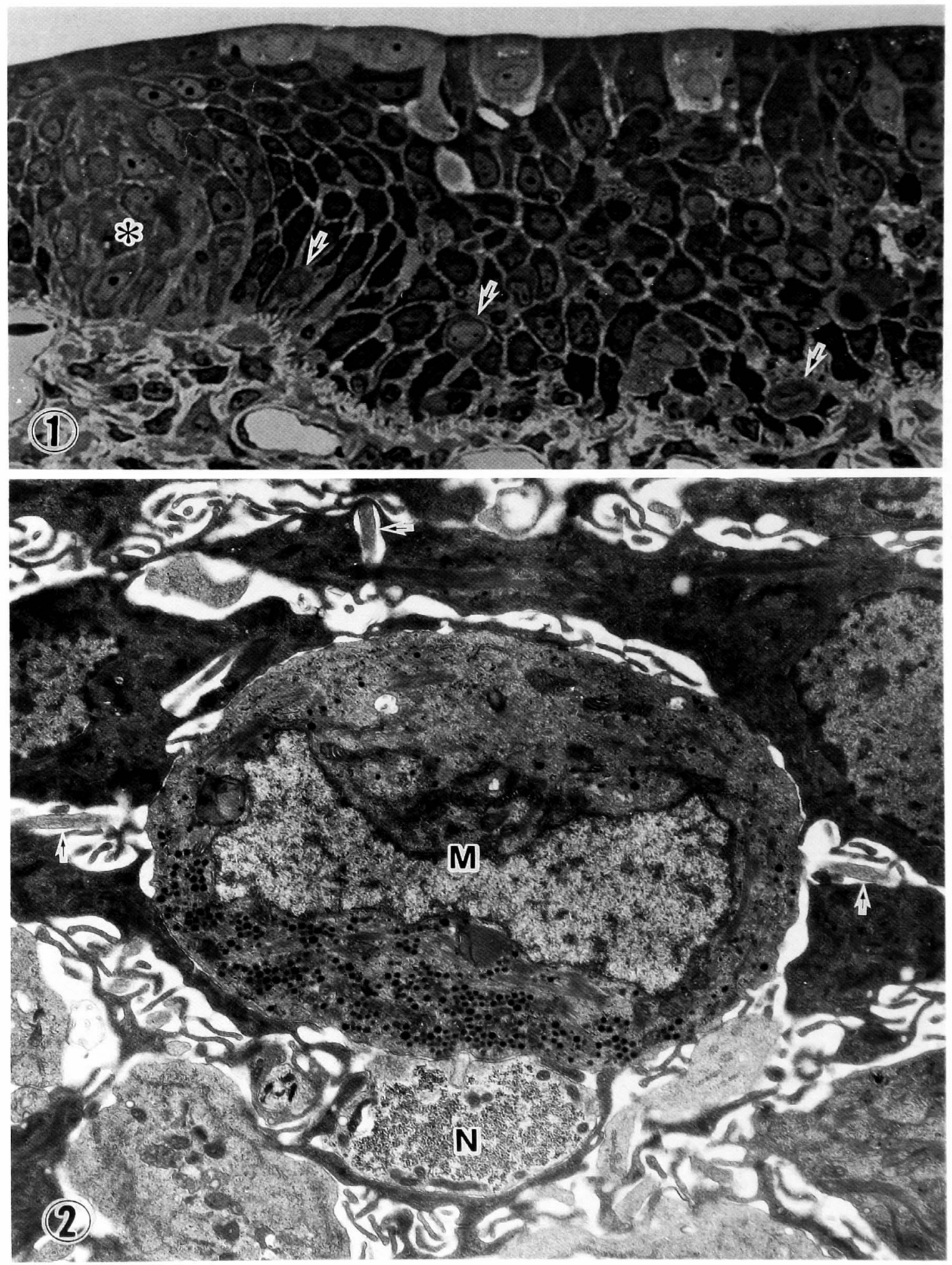




\section{References}

1) Diamond, J., Mills, L. R. and Mearow, K. M.: Evidence that the Merkel cell is not the transducer in the mechanosensory Merkel cell-neurite complex. Prog Brain Res., 74: $51-56,1988$.

2) Düring, M. von.: The ultrastructure of cutaneous receptors in the skin of Caiman corcodilus. Abh. Rhein-Westf. Akad. Wiss. 53: 123-134, 1974

3) Gottschaldt, K. M. and Vahle-Hinz, C.: Merkel cell receptors: structure and transducer function. Science 214: 183-186, 1981.

4) Halata, Z.: The mechenoreceptors of the mammalian skin. Ultrastructure and morphological classification. Adv. Anat. Embryol. Cell Biol., 50: 1-77, 1975.

5) Hartschuh, W., Weihe, E. and Reincke, M.: The Merkel cell. In, Biology of the integument. vol. 2 Vertebrates (ed. Bereiter-Hahn, J., Matoltsy, A. G. and Richards, K. S.), pp. 605-620. Berlin: Springer, 1986.

6) Hartschuh, W., Weihe, E. and Yanaihara, N.: Immunohistochemical analysis of chromogranin A and multiple peptides in the mammalian Merkel cell: Further evidence for its paraneuronal function? Arch. Histol. Cytol., 52(Suppl): 423-431, 1989.

7) Kalt, M. R. and Tandler, B.: A study of fixation of early amphibian embryos for electron microscopy. J. Ultrastruct. Res., 36: 633-645, 1971.

8) Landmann, L. and Halata, Z.: Merkel cells and nerve endings in the labial epidermis of a lizard. Cell Tissue Res. 210: $353-357,1980$
9) Merkel, F.: Tastzellen und Tastkorperchen bei den Hausthiere und beim Menschen. Arch. mikrosk. Anat., 11: $636-652,1875$.

10) Morohunfola, K. A., Jones, T. E. and Munger, B. L.: The differentiation of the skin and its appendages. 1. Normal development of papillary ridges. Anat. Rec., 232: 587-598, 1992.

11) Saxod, R.: Development of cutaneous sensory receptors in birds. In: Handbook of Sensory Physiology, vol. IX, (ed. M. Jacobson), pp. 337-417. Berlin, Heidelberg, New York: Springer, 1978.

12) Tandler, B. and Walter, R.: Epon-Maraglas embedment for electron microscopy. Stain Technol. 52: 238-239, 1977.

13) Toyoshima, K., Miyamoto, K., Itoh, A. and Shimamura, A.: Merkel-neurite complexes in the fungiform papillae of two species of monkeys. Cell Tissue Res., 250: 237-239, 1987.

14) Toyoshima, K. and Shimamura, A.: Ultrastructure of Merkel corpuscles in the tongue of the finch, Lonchura striata. Cell Tissue Res., 264: 427-436, 1991

15) Vos, P., Stark, F. and Pittman, R. N.: Merkel cells in vitro: Production of nerve growth factor and selective interactions with sensory neurons. Develop. Biol., 144: 281-300, 1991.

16) Watanabe, I.: Ultrastructure das células de Merkel da mucosa gingival de lagarto teiú, Tupinambis teguixin (Lacertilia, Teiidae). Rev. Ciênc. Bioméd., Sao Paulo, 9: 43-49, 1988.

17) Whitear, M.: Merkel cells in lower vertebrates. Arch. Histol. Cytol., 52(Suppl): 415-422, 1989.

\section{Plate II}

Fig. 3. Higher-magnification electron micrograph showing a microvillar projection extending from the Merkel cell. $\times 16,000$

Fig. 4. A portion of a Golgi complex in the Merkel cell. Immature dense-cored granules are seen in the Golgi region. $\times 21,000$.

Fig. 5. Electron micrograph showing a Merkel cell devoid of nerve contact and adjoining directly to the basal lamina. Note that a nerve terminal approaching the non-innervated Merkel cell is seen in the subepithelial connective tissue (arrow). $\times 12,000$. 

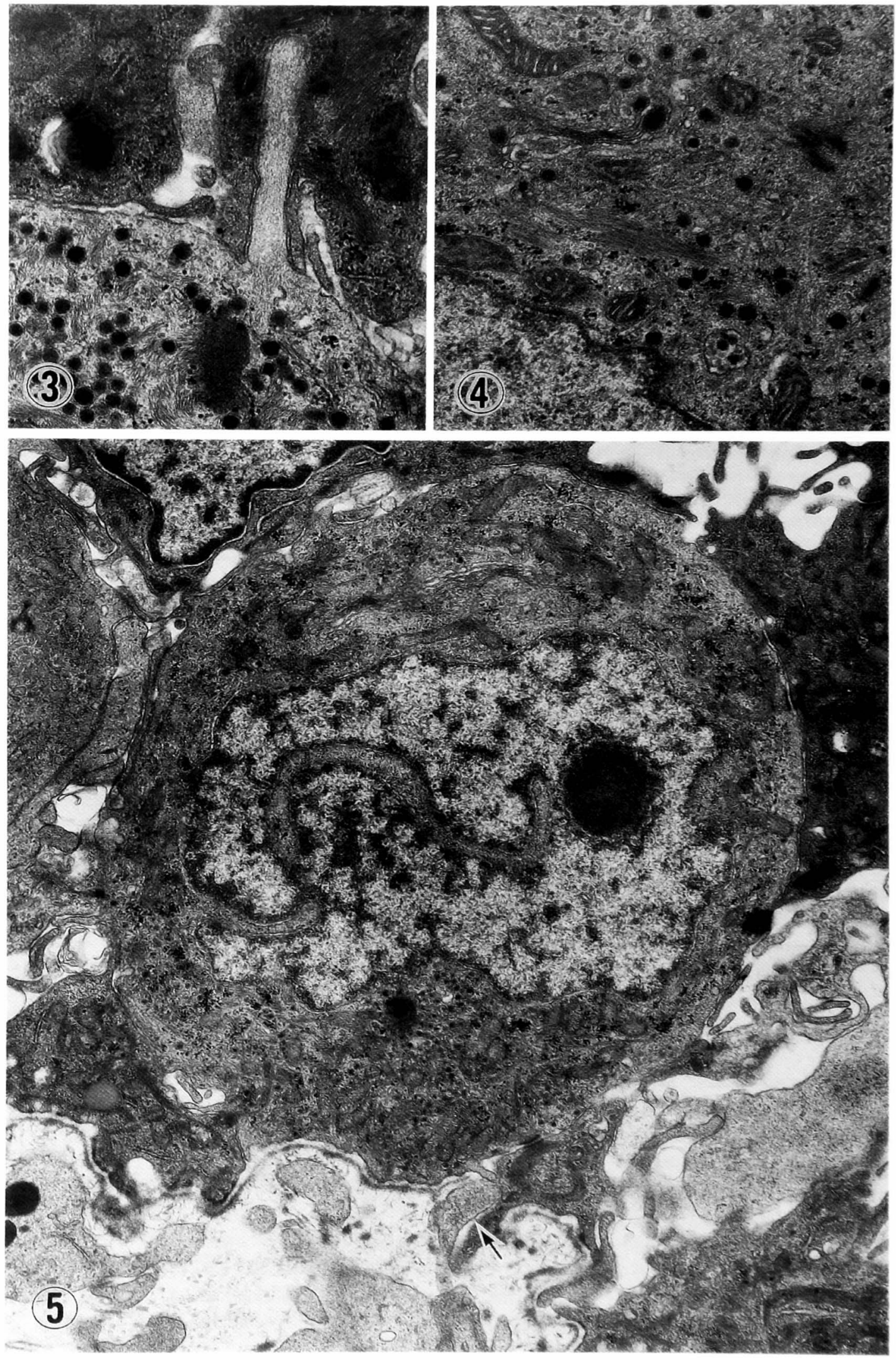